\title{
China's Oil Consumption under Sustainable Development
}

\author{
Z. H. WU \\ China Center for Industrial Security Research of Beijing Jiaotong University, Beijing, China
}

\begin{abstract}
Sustainable development consists mainly of sustainability, fairness, collaboration, the pursuit of the four basic principles of efficiency, Logistic curve analysis is an important tool for sustainable development, the use of comparative analysis of comparative analysis and forecasting. Path oil consumption in line with South Korea and Japan Logistic curve, from supply and demand as well as three alternative energy perspective, China's oil consumption will continue to have much room for growth. For the future of China's oil find a path of sustainable development.
\end{abstract}

KEYWORD: Oil consumption; sustainable development; Logistic curve

\section{ISSUES RAISED}

Deputy Director of Foreign Trade, Ministry of Commerce of China held in Shanghai on the 20th, "The Third China International Petroleum Conference," said the past decade, China's crude oil imports average growth rate of 11.4 percent, refined oil consumption growth rate of $7.2 \%$ on average; 2013 China's oil consumption is 510 million tons, an increase of $3.8 \%$, accounting for $12.1 \%$ of world oil sales, ranking second in the world after the United States. Continued growth in oil demand, making China an important international energy markets stable growth factor.

2013 China's crude oil imports reached 282 million tons, accounting for 15 percent of global crude oil trade, up 1.6 percentage points, $58 \%$ of foreign dependency; imported 4.43 million tons of natural gas, an increase of 48\%, 30\% of foreign dependency. It is predicted that China's crude oil demand in 2015 could reach 540 million tons.

In recent years, China's oil consumption in continuous break record levels, this explosive growth has made China threat theory to support the addition of a theoretical one energy threatened. Therefore, China's oil consumption, as a big country, it is necessary to carry out the reasonable control of domestic oil consumption and improve energy efficiency.

\section{THE CONCEPT OF SUSTAINABLE DEVELOPMENT}

The term "sustainable development" in 1980, "the World Conservation Outline" as the term is proposed for the first time. The concept of sustainable development can be summed up as: "the establishment of minimal waste generation and pollution processes or technology systems in the context of strengthening the production capacity of the environment and update the system so that will not reduce environmental resources, to achieve sustained economic growth and improve quality of life. "Specifically during the operation, sustainable development derived from the corresponding analysis of the four principles, namely sustainability, fairness, collaboration and the pursuit of efficiency. Sustainability refers to the economic development of the Earth's life support systems should not undermine the economic and social development of mankind are not allowed to exceed the carrying capacity of resources and environment; fair can be divided into intra-generational equity and intergenerational equity, require intra-generational poverty eradication as a sustainable development process special priority issues to consider, intergenerational damage is required to ensure that future generations do not realize the benefits of its development; collaboration refers to sustainable development at the global level reflects; the pursuit of efficiency refers to the pursuit of quality issues improvement. 


\section{APPLICATION OF LOGISTIC CURVE}

Logistic curve was originally an important tool for analyzing trends in population growth, the number of trends reflected in the immediate environment constraints, a population. As oil consumption by the population with environmental constraints have similarities, it can also be used to analyze the trends of oil consumption. Logistic growth process can be divided into three stages, the first stage: in the early stages of system development, the role of the limiting factor is small, sufficient environmental capacity drive system with fast pace. Second stage: With the increasing size of the system over time and space development is further reduced, resource supply capacity decreased, limiting environmental conditions improve system more significantly impede growth. The third stage: When approaching the scale of environmental capacity, the system growth rate close to zero.

Demand-supply and the impact of the national economic development of a country's oil consumption will usually go through three stages, the survival stage, stage of development, and sustainable development. In the survival stage, oil consumption in order to meet basic needs and the needs of the few luxury-oriented, slow consumption growth; oil consumption in the beginning stages of development to meet the vast majority of people to improve the living standards of the requirements, the rapid growth in consumption, early rapid growth, late growth smooth; to sustainable development stage, the consumption of oil has basically reached saturation, concussion signs change may occur in some years

\section{THE ANALYSIS CHINA'S OIL CONSUMPTION}

China's oil consumption is mainly influenced by three factors, demand, supply and alternative energy sources

\subsection{Demand Analysis}

Table 1. The main countries in the world per capita oil consumption in 2012

\begin{tabular}{|c|c|c|c|c|c|c|c|}
\hline Country & USA & UK & Japan & Korea & Mexico & Brazil & China \\
\hline $\begin{array}{c}\text { Perception oil } \\
\text { consumption }\end{array}$ & 25.6 & 12.1 & 14.7 & 16.8 & 7.3 & 5.1 & 2.4 \\
\hline
\end{tabular}

Source: US Department of Energy

In 2012 China's per capita oil consumption is only 2.4 barrels / person, relatively developed countries have much room for growth. As the US per capita consumption of resources in the country reached 25.6 barrels of oil per year, while emphasizing environmentally friendly countries such as Japan, the United Kingdom is relatively small consumption, but also reached more than 10 barrels, if China is now developed or near South Korea's oil consumption level, then there is at least about 5 times increase in space, even to achieve the same level of consumption in developing countries Brazil and Mexico, the current oil consumption growth will appear double. Assuming no revolutionary future technology changes, or sudden war, the total crude oil consumption in China than the United States should at least reach the world average per capita of around 5-10 barrels, according to this standard, China's oil cosmetic industry will have multiples of room for growth.

From the development stage, the critical stage in the coming years, China will enter the upgrading of industrial structure, similar to Japan in 1961-1972 and 1983-1994 Korea's economic take-off stage. During this period, steps were heavy chemical industry phase, accelerated urbanization, economic growth will be high growth, high energy consumption as the main performance. Therefore, the rapid growth of China's oil consumption over a period of time will be inevitable fact.

\subsection{Supply factors}

China's supply of oil is divided into two parts, domestic supply and international supply.

Domestic supply parts: 2001 Chinese oil reserves of 21.759 billion tons, recoverable reserves of 6.204 billion tons, remaining recoverable reserves of 2.408 billion tons. China belongs to the total oil resources are relatively rich countries, but the size of the absolute number of poor and can not cover the per capita indicators, China's per capita share of oil resources is only $12.1 \%$ compared to the world average per capita remaining recoverable reserves only $8.4 \%$ of the world average value. China's oil consumption from the beginning of 1993 needs to be imported to make up for the lack of domestic production, the future of China's oil production has not improved much, basically to maintain the production stage, and mining conditions remaining reserves also began deterioration, mining costs, which limits the ability to improve China's domestic supply of oil from the root. Therefore, under the premise of the domestic oil supply has been basically saturated, the Chinese oil supply will mainly rely on imports to complete.

International Supply: 2009 world oil production is about 80 million barrels, the next incremental oil supply comes mainly from Russia and Africa in the past non-OPEC countries, oil demand in China and India significantly increased, global oil production will continue to push higher. But crude oil prices do not continue for a long time, for two reasons: The first factor is still much larger than the existing oil 
reserves may demand, but because of cost considerations, a considerable number of oil reserves has not been mined such as Canada's rich ore resources and deepwater Gulf of Mexico, as well as one of the biggest variable is Russia, a vast Siberian region of Russia, yet there is a large area of exploration potential of this region have not yet been fully realized. Thus, the global oil supply is still a great upside. The second factor is OPEC oil organization such factors, in view of the high oil prices on the world economy to rebound in oil demand inhibition, OPEC will automatically increase production to stabilize prices and prevent undue influence of oil price changes on the world economy.

Table 2. Chinese domestic oil supply and demand balance

\begin{tabular}{|c|c|c|c|}
\hline Years & Production & Demand & Gap \\
\hline 1980 & 10594 & 8757 & 1837 \\
\hline 1990 & 138330 & 11485 & 2345 \\
\hline 1995 & 15005 & 16064 & -1059 \\
\hline 2000 & 16300 & 22400 & -6100 \\
\hline 2005 & 18135 & 32538 & -14402 \\
\hline 2010 & 22300 & 25400 & -21100 \\
\hline
\end{tabular}

Source: National Bureau of Statistics

\subsection{Alternative Energy Factors}

Oil consumption forecast is a science, but also an art, this prediction biggest variable from alternative energy sources. Oil has many alternative energy, specifically coal, natural gas, and solar energy.

\subsubsection{Coal}

Table 3. China's coal production

\begin{tabular}{|c|c|c|c|c|c|}
\hline Years & 1980 & 1990 & 2003 & 2005 & 2008 \\
\hline $\begin{array}{c}\text { Coal production } \\
\text { (million tons) }\end{array}$ & 6.2 & 10.8 & 16.67 & 23.50 & 28.02 \\
\hline
\end{tabular}

Source: National Bureau of Statistics

China's coal production showed an increasing trend, and to achieve substantial exports. But coal for oil alternatives is relatively small, if there is no breakthrough technology to solve the problem of storage and use of gas, coal and oil alternative is not large.

\subsubsection{Natural gas}

Table 4. China natural gas output

\begin{tabular}{|c|c|c|c|c|c|}
\hline Years & 1999 & 2000 & 2003 & 2005 & 2008 \\
\hline $\begin{array}{c}\text { Natural gas } \\
\text { production }\end{array}$ & 24.3 & 27.2 & 35.0 & 48.0 & 76.1 \\
\hline
\end{tabular}

Source: National Bureau of Statistics
China's natural gas reserves are relatively abundant, natural gas and coal is the same problem exists, there is a series of problems storage and use, so if there is not much change in the price of oil, the relevant technology is still not receive strong impetus.

\subsubsection{Solar energy, liquid hydrogen, etc.}

China is the world's solar energy superpower. But solar car or hydrogen cars appeared just a test, it will take a long time to replace petroleum effort.

\subsection{Comprehensive analysis}

China's oil consumption is the limiting factor being mainly from the increase in international supply, within a limited period of time, as prices increase, will cause an increase in alternative energy sources and development of new oil fields, so basically you can believe that China's oil consumption is guaranteed, the main limiting factor from the Chinese economic growth and industrial structure upgrading itself. Here in Japan and South Korea economic growth in oil consumption when, for example, analysis of China's oil consumption in the coming years.

Japan from 1961-1972 years, 12 years, rapid economic take-off, the average economic growth rate of $9.8 \%$, oil consumption rose from 0.82 million barrels per day to 4.36 million barrels a day old old, 12 years quadrupled. South Korea from 11 years of economic takeoff in 1983 to 1994, the annual average economic growth rate of $8.8 \%$, oil consumption increased to 1.84 from 0.56 million barrels a day old old barrels, an increase of nearly 3 times. From the experience of Japan, South Korea, China stage in which its roughly similar, in the late heavy industry is, therefore, China's oil consumption will probably 10-15 years in line with the international average. Japan's oil consumption curve Korea, in line with changes Logistic style, we can make such estimates, since 2006, China's oil consumption will always maintain the existing sustained rapid growth to reach around 2015 growth vertex, then the growth rate of oil consumption will start smoothly. By 2020, China's per capita oil consumption will be achieved with international standards, reaching 5-10 barrels per person per year, which is the current consumption of crude oil will remain fairly level of growth within a certain time.

Uncontrollable factors: technological advances may change the path of oil consumption, while supply-side factors may also affect changes in consumption path. Moreover, China's demand influenced by macro-control is relatively large, and therefore, there will be more intense changes in some years. 


\section{CHINA'S OIL CONSUMPTION FORECAST}

China's oil consumption has not yet reached the saturation point, the next few years, China's oil consumption will continue to grow, so we not only want to expand oil production in the country, but also to deepen international cooperation, expand oil trade is to enhance China's energy security, achieve an important means of economic and social development. Continued growth in oil demand in the Chinese market, and promote the market prosperity, greater global interdependence and mutually beneficial relationship with the world of energy, oil and gas development and led to the widespread application of new technologies has become an important international energy markets stable growth factor.

China will vigorously promote the development of unconventional oil and gas resources, to promote wind power, solar energy, nuclear power and other non-fossil energy sources and new energy development is also an important measure for China to promote energy production revolution. China and strive to achieve in 2030 the proportion of non-fossil energy third, in 2050 the proportion of non-fossil energy half goals. China will greatly enhance the fossil energy safe, efficient, clean production level, for 2030, green mining and clean coal conversion technologies widely used, the initial formation of a safe, efficient, green fossil energy production system. These are the direction of our government and business development needs.

\section{REFERENCES}

[1] Lincoln. Julian Simon did not limit growth (last resource) ,Sichuan People's Publishing House, 1985

[2] P. Di Weinuo ecology Introduction, Science Press, 1987

[3] China Contemporary International Relations Institute of Economic Research Center of Global Energy Security great game, Current Affairs Press, 2005 (01)

[4] Masih, Abul 1VL1VLa; Masih, Rumi, "Energy consumption, real income and temporal causality: results from a multi-country study based on co-integration and error-correction modelling techniques", Energy Economics, 1996, Vo118- p 165.

[5] Asafu-Adjaye, Johna, "The relationship between energy consumption, energy prices and economic growth: time series evidence from Asian developing countries", Energy Economics, 2000, Vo122, p615.

[6] Hondroyiannis, Georgea; Lolos, Sarantisb; Papapetrou, Evangeliac," Energyconsumption and economic growth: assessing the evidence from Greece", Energy Economics, 2002, Vo124, p319.

[7] Jumbe, Charles B.L., Co integration and causality between electricity consumption and GDP: empirical evidence from Malawi”, Energy Economics, 2004, Vo126, p61.

[8] Paul, Shyamala; Bhattacharya, Rabindra N.b, Causality between energy consumption and economic growth in India: anote on conflicting results, Energy Economics, 2004, Vo126, p977.

[9] Oh, Wankeuna; Lee, Kihoonb, Energy consumption and economic growth in Korea: testing the causality, Journal of Policy Modeling, 2004, Vo126, p973. 